\title{
ALTERNATIF STRATEGI PENGELOLAAN SAMPAH BERBASIS PEMBERDAYAAN MASYARAKAT MELALUI BANK SAMPAH DI DESA TUNJUK, TABANAN
}

\author{
Luh Gede Mita Laksmi Susanti ${ }^{1}$, Ni Nyoman Juwita Arsawati ${ }^{2}$ \\ 1Program Studi Manajemen, Universitas Pendidikan Nasional \\ ${ }_{2}^{2}$ Program Studi Ilmu Hukum, Universitas Pendidikan Nasional \\ Email : $\underline{\text { mitalaksmi42@gmail.com ,2 juwitaarsawati@undiknas.ac.id }}$
}

\begin{abstract}
Abstrak
Permasalahan sampah merupakan polemik klasik yang tidak berujung dimasyarakat. Permasalahan dalam pengelolaan sampah di Desa Tunjuk, Tabanan cukup berat dimana ksadaran dan kepedulian masyarakat masih kurang terhadap pengelolaan sampah rumah tangga. Masyarakat masih membuang sampah sembarangan dan membakar sampah. Tujuan kegiatan ini yaitu memberikan gagasan pemberdayaan masyarakat dengan alternatif solusi berupa edukasi pengelolaan sampah rumah tangga. Metode yang digunakan yaitu penyuluhan dan penyebaran poster. Penyuluhan mengenai edukasi pengelolaan sampah menggunakan metode SOS (sort out, saved) dengan prinsip 3R (reduce, reuse, dan recycle) dan memahami peran bank sampah. Kemudian dilanjutkan dengan penyebaran poster pengelolaan sampah dengan konsep 3R. Hasil pengabdian kepada masyarakat yaitu meningkatkan motivasi warga desa dan merubah pola pikir mereka mengenai kesadaran lebih peduli terhadap lingkungan dan diharapkan untuk segera membuat kesepakatan dengan perangkat desa untuk membentuk bank sampah guna meminimalisir adanya timbulan sampah. Gagasan dibentuk bank sampah sekiranya dapat membantu mengatasi permasalahan sampah rumah tangga di Desa Tunjuk, guna menumbuhkan kesadaran dalam pengelolaan sampah untuk memperoleh manfaat secara langsung, baik secara ekonomi dan kesehatan lingkungan.
\end{abstract}

Kata Kunci: Strategi, Pengelolaan Sampah, Bank Sampah

The waste problem is a classic polemic that does not end in society. The problem in waste management in Tunjuk Village, Tabanan is quite serious, where the community's awareness and concern for household waste management are still lacking. People still litter and burn rubbish. The purpose of this activity is to provide ideas for community empowerment with alternative solutions in the form of household waste management education. The method used is counseling and poster distribution. Counseling on waste management education uses the SOS method (sort out, saved) with the 3R principle (reduce, reuse, and recycle) and understands the role of waste banks. Then proceed with the distribution of waste management posters with the $3 \mathrm{R}$ concept. The result of community service is to increase the motivation of the villagers and change their mindset regarding awareness of being more concerned about the environment and it is hoped that they will immediately make an agreement with village officials to form a waste bank to minimize the presence of waste generation. The idea of forming a waste bank is to help solve the problem of household waste in Tunjuk Village, in order to raise awareness in waste management to obtain direct benefits, both economically and environmental health.

Keywords: Strategy, Waste Management, Waste Bank 


\section{PENDAHULUAN}

Terjadinya pandemi global saat ini yang disebabkan oleh virus covid-19 yang berdampak pada pencapaian dari Tujuan Pembangunan Berkelanjutan atau Sustainable Development Goals (TPB/SDGs) 2030. Adanya anjuran pembatasan terhadap aktivitas manusia berpengaruh dalam berbagai kegiatan seperti ekonomi, dan beberapa sektor industri. Dengan adanya kebijakan pembatasan sosial dan juga lockdown memiliki dampak positif seperti penurunan emisi $\mathrm{CO} 2$ dunia sampai $17 \%$ selama karantina yang diterapkan diberbagai negara. Selain itu juga berdampak positif terhadap keanekaragaman hayati flora dan fauna. Namun, kebijakan tersebut secara tidak langsung berdampak negatif yaitu adanya peningkatan timbulan sampah plastik dan sampah medis. Menurut Lembaga Ilmu Pengetahuan Indonesia, peningkatan sampah plastik domestik dari 1-5 menjadi 5-10 gram per hari oleh setiap individu. Kementerian Lingkungan Hidup dan Kehutanan mencatat saat ini adanya peningkatan pada produksi limbah medis sebanyak 290 ton limbah medis per hari (Suryani, 2020).

Sampah merupakan bahan-bahan atau benda yang dibuang karena tidak dapat digunakan kembali. Berdasarkan UU No.18 Tahun 2008, definisi sampah merupakan sisa kegiatan sehari-hari oleh manusia atau proses alam yang memiliki bentuk padat atau semi padat berupa zat organik atau anorganik bersifat dapat terurai atau tidak dapat terurai dan sudah tidak berguna lagi yang kemudian dibuang.

Menurut Daniel (2009) pembagian sampah dibagi menjadi tiga jenis yaitu sampah organik, sampah anorganik, dan sampah bahan berbahaya dan beracun (B3) (Juniartini, 2020). Sampah organik adalah bahan yang dapat terurai melalui proses alamiah/biologis. Sampah jenis ini biasa disebut dengan sampah basah seperti sisa makanan, daun, dan lainlain. Sampah anorganik merupakan sampah yang sulit terurai dengan proses biologis dalam waktu jangka panjang. Sampah ini disebut sampah kering seperti plastik, styrofoam, kaleng. Dan sampah B3 merupakan limbah yang berasal dari bahan-bahan berbahaya dan juga beracun seperti limbah pabrik tekstil, limbah rumah sakit, dan lain lain.

Masalah sampah merupakan polemik klasik yang tidak berujung dimasyarakat. Masalah sampah tidak akan pernah habis jika kurangnya kesadaran masyarakat mengenai hal tersebut. Adanya manajemen pengelolaan sampah yang baik sangat diperlukan dalam mengelola dan menjaga lingkungan untuk tetap bersih dan asri. Berdasarkan undangundang Nomor 18 tahun 2008 tentang Pengelolaan Sampah disebutkan bahwa peran masyarakat turut berpatisipasi dalam pengelolaan sampah rumah tangga, dalam hal pengurangan (meliputi kegiatan pembatasan, penggunaan kembali, dan pendauran ulang) dan penanganan sampah (meliputi pemilahan, pengumpulan, pengangkutan, pengolahan, dan pemrosesan akhir). Pengelolaan sampah tidak hanya dilakukan pada jangkauan wilayah perkotaan saja, namun juga mencakup wilayah perdesaan.

Kondisi pengelolaan sampah rumah tangga di Desa Tunjuk, Tabanan cukup buruk. Kurangnya kesadaran dan kepedulian masyarakat terhadap pengelolaan sampah rumah tangga dikarenakan kebiasaan masyarakat membuang sampah rumah tangga di selokan dan dibelakang rumah yang kemudian dibakar. Akibatnya, kebiasaan sikap yang tidak disiplin mengenai kebersihan ini membuat timbulan sampah bertambah seiring waktu dan hasil bakaran tersebut berdampak pada pencemaran ekosistem tanah dan polusi dilingkungan desa. Timbulan sampah ini terus menumpuk dibelakang rumah pemukiman para warga. Tidak tersedianya TPS maupun TPA di desa ini juga menjadi alasan hal tersebut dilakukan.

Melalui pemberdayaan masyarakat untuk mengatasi permasalahan sampah melalui pengelolaan sampah menjadi barang yang bisa menghasilkan dari segi nilai maupun financial (Istiqomah, Mafruhah, \& Gravitiani, 2020). Peranan bank sampah dalam peningkatan kesadaran masyarakat dengan 
pengelolaan sampah rumah tangga bisa menjadi solusi bagi permasalahan sampah ini.

Tujuan kegiatan pengabdian kepada masyarakat ini yaitu untuk mengetahui cara pengelolaan sampah hasil rumah tangga dan memberikan edukasi berupa solusi dalam pengelolaan sampah hasil rumah tangga di Desa Tunjuk melalui penyuluhan bank sampah. Sehingga melalui alternatif solusi yaitu memberikan penyuluhan terhadap pentingnya pengelolaan sampah rumah melalui bank sampah sekiranya dapat membantu mengatasi permasalahan sampah rumah tangga di Desa Tunjuk, guna menumbuhkan kesadaran dalam pengelolaan sampah untuk memperoleh manfaat secara langsung, baik secara ekonomi dan kesehatan lingkungan agar terciptanya lingkungan hijau, sehat, dan nyaman. Dengan demikian melalui hasil laporan ini, diharapkan peneliti dapat memberikan gagasan/ide sebagai alternatif strategi bagi warga desa dalam pentingnya pengelolaan sampah rumah tangga berbasis pemberdayaan masyarakat melalui Bank Sampah di Desa Tunjuk, Tabanan.

\section{METODE PELAKSANAAN}

Metode kegiatan dalam pelaksanaan pengabdian kepada masyarakat di Desa Tunjuk ini dimulai dari identifikasi masalah, penyuluhan, dan penyebaran poster. Kegiatan penyuluhan mengenai edukasi pengelolaan sampah menggunakan metode SOS (sort out, saved) dengan prinsip 3R (reduce, reuse, dan recycle) dan peranan bank sampah dalam desa. Kegiatan ini diikuti oleh Kegiatan penyuluhan mengenai pengelolaan sampah ini dilakukan pada hari minggu, 14 Februari 2021 pada pukul 10.00 wita yang diikuti oleh 25 peserta. Kemudian dilanjutkan dengan kegiatan penyebaran poster pengelolaan sampah dengan konsep 3R. Kegiatan ini dilakukan pada hari minggu, 21 Februari 2021 pada pukul 16.00. Penyebaran poster dilakukan di delapan tempat publik seperti di depan warungwarung yang biasa dikunjungi oleh warga Desa Tunjuk.

Penerapan prinsip 3R ini merupakan perubahan paradigma dimasyarakat mengenai pengelolaan sampah yang bersifat konvensional menjadi suatu paradigma baru, dimana sampah yang awalnya tidak memiliki nilai dapat dimanfaatkan hingga memiliki nilai yang menjadi sumber penghasilan dan pembukaan bagi lapangan pekerjaan (Nasirudin \& Triastianti, 2018).

Dalam sistem 3R, reduce merupakan pengurangan penggunaan sampah dengan cara menghemat pemakaian barang agar tidak menimbulkan sampah yang berlebih sehingga adanya timbulan sampah. Reuse yaitu memanfaatkan kembali sampah yang masik layak digunakan. Recycle yaitu mendaur ulang sampah yang diolah menjadi barang yang bisa digunakan kembali.

Penyuluhan dan penyebaran poster dilaksanakan dengan tujuan untuk memberikan pemahaman mengenai pemilahan sampah dan pengelolaan sampah menjadi bernilai ekonomis agar terkelolanya sampah di desa sehingga dapat mengatasi permasalahan sampah. Kegiatan - kegiatan tersebut meliputi memberikan edukasi mengenai pemilahan sampah yang dikumpulkan dan kemudian di tabung dengan harapan output tersebut dapat berdampak sosial dan lingkungan yang baik (Wartama \& Nandari, 2020).

\section{HASIL DAN PEMBAHASAN}

Berdasarkan identifikasi permasalahan maka dirumuskan beberapa program kegiatan yaitu pelaksanaan penyuluhan secara daring bagi kelompok karang taruna dan organisasi ibu-ibu PKK di Desa Tunjuk guna meningkatkan pemahaman dan pengetahuan masyarakat dalam pengelolaan sampah menjadi nilai ekonomis melalui pembentukan bank sampah di Desa Tunjuk. Hasil dari kegiatan penyuluhan mengenai pengelolaan sampah 3R melalui bank sampah ini sangat diterima dengan antusias oleh kelompok karang taruna dan organisasi ibu-ibu PKK Desa Tunjuk.

Melalui penyuluhan mengenai bank sampah akan berdampak positif baik secara ekonomi, sosial, maupun lingkungan. Kegiatan pengabdian kepada masyarakat ini bersifat social engineering dikarenakan membantu dan mengajarkan masyarakat dalam memilah sampah guna menumbuhkan kesadaran 
masyarakat melalui pengelolaan sampah guna memperoleh manfaat secara langsung, baik secara ekonomi, terwujudnya kesehatan lingkungan yang bersih, hijau, nyaman, dan sehat.

Penyuluhan gagasan mengenai bank sampah ini, yaitu memberikan informasi dan pemahaman bagi warga desa mengenai sistem kerja bank sampah melalui proses pengumpulan serta pemilahan sampah sampah nonorganik disesuaikan dengan jenis dan kategori yang kemudian ditimbang dan ditabung di bank sampah. Manfaat yang dapat dirasakan jika warga membentuk bank sampah yaitu masyarakat akan mendapat profit dengan mengumpulkan sampah sesuai dengan jenis dan jumlah yang ditentukan per-kg nya.

Jika bank sampah ini dibentuk, anggota ataupun nasabah akan menyetorkan sampah anorganik yang akan dilakukan pencatatan kemudian ditimbang dan akhirnya memiliki harga sesuai dengan akumulasi jumlah sampah yang dikumpulkan oleh nasabah, dikalikan dengan daftar harga yang telah ditentukan oleh pengurus bank sampah dengan memperhitungkan biaya penyusutan kelengkapan bank sampah dan keuntungan bagi para nasabah.

Melalui penyuluhan tersebut juga diinformasikan teknis kepengurusan bank sampah yakni akan dilakukan melalui pemberdayaan masyarakat lokal yaitu bisa dengan kelompok karang taruna atau organisasi PKK setempat. Kegiatan penabungan sampah dilakukan satu bulan sekali yang dilakukan pada hari minggu. Teknis kerja penimbangan sampah akan dilakukan oleh anggota ataupun nasabah bank sampah yaitu melakukan pemilahan sampah berdasarkan jenis yang kemudian nantinya akan ditabung setiap dua minggu sekali. Prasarana buku tabungan dimiliki oleh setiap anggota atau nasabah Bank Sampah Desa Tunjuk sebagai pencatatan hasil dari penimbangan sampah yang kemudian hasilnya bisa diambil kapan saja (fleksibel) menyesuaikan dengan keinginan dari nasabah.

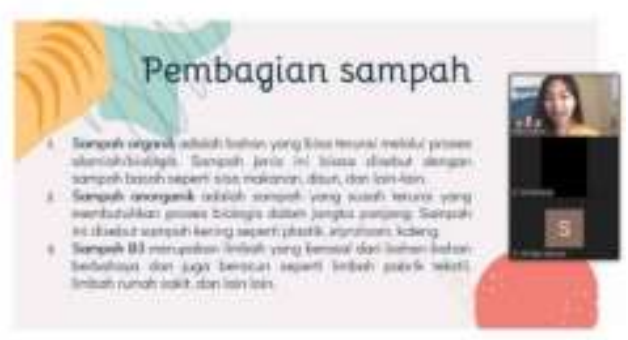

Gambar 1. Penyuluhan pengelolaan sampah melalui zoom meeting

Setelah dilaksanakan kegiatan penyuluhan, selanjutnya dilaksanakan kegiatan penyebaran poster mengenai pengelolaan sampah dengan konsep 3R (reduce, reuse, dan recycle). Penyebaran poster dilakukan di delapan tempat publik seperti di depan warung-warung yang biasa dikunjungi oleh warga Desa Tunjuk.

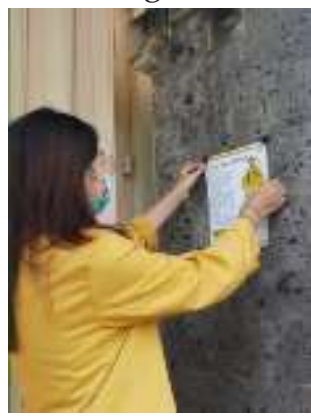

Gambar 2. Penyebaran poster pengelolaan sampah 3R

Adapun indikator keberhasilan kegiatan pengabdian kepada masyarakat yaitu nilai sosial, nilai ekonomi, dan lingkungan. Dalam indikator nilai sosial, sebelum adanya pengabdian yaitu kurangnya rasa kepedulian masyarakat terhadap penanganan sampah dilingkungan sekitar. Kemudian solusi yang diberikan yaitu membantu masyarakat dengan memberikan pemahaman melalui penyuluhan dan penyebaran poster mengenai pentingnya menciptakan kebiasaan lingkungan bersih dan sehat.

Dalam indikator nilai ekonomi, sebelum adanya pengabdian pemahaman dimasyarakat mengenai penanganan sampah hanya dengan membayar biaya pengangkutan sampah. Solusi yang ditawarkan yaitu membantu masyarakat untuk memberikan pemahaman mengenai edukasi dalam pembentukkan bank sampah di desa, sehingga sampah yang terkumpul dalam proses 
penabungan dapat memberikan hasil ekonomis. Hasil pengabdian yang terjadi yakni masyarakat akan mendapatkan penghasilan melalui kegiatan penabungan sampah di bank sampah yang kemudian dijual ke pengepul sampah.

Dalam indikator lingkungan, sebelum adanya pengabdian yakni kurangnya penanganan sampah oleh warga setempat sehingga berdampak pada adanya permasalahan dilingkungan sekitar. Kemudian solusi atas permasalahan tersebut yaitu memberikan pemahaman mengenai pemilahan dan pengelolaan sampah. Hasil setelah pengabdian yaitu lingkungan akan menjadi bersih dan sehat.

\section{KESIMPULAN DAN SARAN}

\section{Kesimpulan}

Masalah sampah merupakan polemik klasik yang tidak berujung dimasyarakat. Dari kegiatan pengabdian kepada masyarakat yang telah dilakukan, adanya peningkatan pengetahuan dan pemahaman masyarakat di Desa Tunjuk mengenai cara pengelolaan sampah yang baik dengan konsep $3 \mathrm{R}$ dan melalui pemberdayaan bank sampah. Meningkatnya kesadaran masyarakat Desa Tunjuk untuk tidak membuang sampah sembarangan di sungai dan tidak membakar sampah sehingga kesadaran dan kepedulian lingkungan dan kesehatan. Bertambah optimal kesadaran masyarakat dalam membuang sampah dan meminimalisir penggunaan sampah anorganik dan berkurangnya dampak negatif dari sampah bagi kesehatan dan lingkungan. Dan juga bertambahnya wawasan masyarakat mengenai pentingnya bank sampah dalam pengelolaan sampah di desa untuk merencanakan pembentukkan bank sampah bagi desa.

\section{Saran}

Saran keberlanjutan untuk kegiatan ini yaitu diperlukan upaya perbekel dan warga Desa Tunjuk dalam menghadapi kendala kendala pada permasalahan lingkungan melalui pembentukkan bank sampah. Melalui upaya sosialisasi secara bertahap serta rutin mengenai pengelolaan sampah melalui bank sampah sehingga dapat terselenggara dengan baik dan konsisten, dan kesadaran masyarakat akan pentingnya mengelola sampah dapat meningkat. Struktur bank sampah bisa dilakukan dengan pemberdayaan masyarakat yaitu ibu-ibu PKK ataupun kelompok karang taruna. Dengan kegiatan - kegiatan tersebut diharapkan secara bertahap pola pikir masyarakat mengenai pemahaman pengelolaan sampah dan pembentukkan bank sampah dapat berjalan dengan baik.

\section{DAFTAR REFERENSI}

Dewanti, M., Purnomo, E. P., \& Salsabila, L. (2020). Analisa Efektifitas Bank Sampah Sebagai Alternatif Pengelolaan Sampah Dalam Mencapai Smart City Di Kabupaten Kulon Progo. Jurnal Ilmu Administrasi Publik, 23-24.

Istiqomah, N., Mafruhah, I., \& Gravitiani, E. (2020). Konsep Reduce, Reuse, Recycle Dan Replace Dalam Pengelolaan Sampah Rumah Tangga Di Desa Polanharjo Kabupaten Klaten. 30-38.

Juniartini, N. L. (2020). Pengelolaan Sampah Dari Lingkup Terkecil Dan Pemberdayaan Masyarakat Sebagai Bentuk Tindakan Peduli Lingkungan. Jurnal Bali Membangun Bali, 28-29.

Nasirudin, \& Triastianti, R. (2018). Potensi Reduce, Reuse, Recycle (3r) Sampah Domestik Pada Bank Sampah Di Kecamatan Umbulharjo Dan Kecamatan Pakualaman Kota Yogyakarta. Seminar Nasional \& Call For Paper, 114-115.

Republik Indonesia. (2008). UndangUndang (Uu) No. 18 Tahun 2008 Tentang Pengelolaan Sampah. Jakarta.

Suryani, A. S. (2020). Dampak Pandemi Covid-19 Terhadap Lingkungan Global. Jakarta Pusat: Pusat Penelitian Badan Keahlian Dpr Ri.

Wartama, I. W., \& Nandari, N. S. (2020). 
Pemberdayaan Masyarakat Dalam

Pengelolaan Sampah Rumah

Tangga Melalui Bank Sampah Di

Desa Sidakarya Denpasar Selatan.
Parta: Jurnal Pengabdian Kepada Masyarakat, 45-46. 